\title{
Ethnicity, religiosity and SME innovation outcomes: some insights from a Muslim ethnic group
}

\section{Donard Games}

Department of Management,

Universitas Andalas,

Kampus Limau Manis, Padang, 25163,

West Sumatra, Indonesia

Email: donardgames@eb.unand.ac.id

\begin{abstract}
The paper aims to examine the effects of socio-cultural factors (i.e., socio-cultural values, ethnicity, and religiosity) on business innovation (i.e., SME innovation outcomes) in an entirely Muslim ethnic (i.e., Minangkabau ethnic group in Indonesia). There has been little research done to reveal the relationship between ethnicity, societal values, religiosity, and innovation outcomes in a totally Muslim community. The present study uses a quantitative approach, PLS method, that utilises SmartPLS 4.0. A survey of 150 Muslim respondents from the Minangkabau ethnic small and medium-sized enterprises had been carried out. It was found that ethnicity had no impact on the SME innovation outcomes. Likewise, religiosity did not moderate the relationship between ethnicity and innovation outcomes. Minangkabau societal values which are a unity between Islamic values and tradition have a positive and significant effect on the innovation outcomes. Implicitly, maximising Minangkabau networks that prioritises the values of cooperation, honesty and trustworthiness will enhance Minangkabau SME innovation outcomes.
\end{abstract}

Keywords: ethnicity; ethnic entrepreneurship; Islamic religiosity; religiosity; SME innovation; innovation outcomes; business innovation; Minangkabau; Indonesia; socio-cultural factors; Islamic entrepreneurship; Muslim ethnic group.

Reference to this paper should be made as follows: Games, D. (2020) 'Ethnicity, religiosity and SME innovation outcomes: some insights from a Muslim ethnic group', World Review of Entrepreneurship, Management and Sustainable Development, Vol. 16, No. 4, pp.430-444.

Biographical notes: Donard Games is a Lecturer at the Department of Management, Universitas Andalas, Indonesia. He gets his $\mathrm{PhD}$ from the University of Western Australia Business School. His research interests include SME innovation, ethnic entrepreneurship and Islamic entrepreneurship.

\section{Introduction}

Business innovation has become a necessity and an opportunity for small and medium enterprises (SMEs). It is imperative for them to innovate as it is required in today's highly competitive era. Innovation may beneficial for firms such as SMEs in enhancing business growth and financial performance (Suriyankietkaew, 2019). Conducting 
innovation also signifies an organisation's willingness and ability to deal with changes (Damanpour, 1996). Without innovation, SMEs will stagnate especially in the context of intense competitions with abundant business opportunities such as in emerging market economies. Accordingly, the most important question is whether SMEs can benefit from innovation.

The literature reviews show that some innovation-related constructs have positive effects on innovation outcomes. These are, for example, creativity (Amabile, 1996), organisational structure (Soutar and McNeil, 1993), human resource competencies (Sawang and Unsworth, 2011), and leadership with the right approach (Ratam, 2005). However, innovation may not always result in real and immediate positive outcomes as it may also cause negative outcomes (Simpson et al., 2006). The present study focuses on cultural factors that lead to SME innovation outcomes. This is needed to be further explained in-depth. The present study examines the effects of socio-cultural factors (i.e., socio-cultural values, ethnicity, and religiosity) on business innovation (i.e., SME innovation outcomes) in an entirely Muslim community (i.e., Minangkabau ethnic group in Indonesia). This is in the context of a Muslim community that is known to have a high culture and religiosity (Elfindri et al., 2010; Sari, 2014).

As suggested by Ramadani et al. (2015), there is a strong link between societal values and entrepreneurship as the former is related to the context and culture where entrepreneurs reside. In this case, ethnicity and religiosity may be seen as sources of entrepreneurship. That is why the present study follows the conceptualisation of Dana (2009) and Dana et al. (2020) that considers religiosity and ethnicity as foundation of social capital which in turn leads to entrepreneurship. Furthermore, the present study examines whether both ethnicity and religiosity in a particular Muslim society may result in better innovation outcomes. Both innovative behaviour and innovative activities have been regarded as key points indicating the level of entrepreneurship, more specifically ethnic entrepreneurship (Ramadani et al., 2014). In the present study, innovation outcomes have been seen as representative of successful Minangkabau entrepreneurship considering their struggle within the context of Minangkabau.

In particular, this research was conducted to:

1 examine the relationship between the values of Minangkabau culture, ethnicity and SME innovation outcomes

2 examine the role of religiosity whether this variable moderates the relationship between the values of Minangkabau culture, ethnicity and SME innovation outcomes.

The reason why Minangkabau is chosen as the focus of this study is the fact that the Minangkabau is widely accepted as a source of entrepreneurs. As suggested by Mangundjaya (2011), they were embracing innovation. The philosophy of the community is 'adat basandi sara'; sara 'basandi kitabullah' (Adat based on religion; and religion based on the Koran). This shows how attached the role of adat (tradition) and especially religion (Islam) as values and identity of Minangkabau people (Abdullah, 1966). It is interesting and important to know whether these things really influence the achievements of the Minangkabau business innovation. If so, then this path of cultural and Islamic value-based innovation can become a strong foundation for further research in the context of societies with strong culture and religiosity. 
Few researches have been done that focused on Minangkabau SME innovation with a unique position of cultural values and strong Islamism. A number of evidences have shown that Minangkabau people do have values that conform to entrepreneurial values, such as openness to change (Mangundjaya, 2011; Games et al., 2013). However, there has been no continuation of the research in terms of investigating the role of religiosity and how it relates to the achievement of innovation. Research on this matter will provide an understanding of how the values of Minangkabau culture and appreciation of religion (Islam) benefit SME innovation outcomes.

\section{Literature review}

This part discusses the concepts underlying this research, namely socio-cultural values, Minangkabau culture, religiosity, and innovation outcomes. Furthermore, the role of religiosity as a moderating factor is also discussed. The most important notion in the review of the literature is that while there is a strong link between cultural values, religiosity, and innovation (as a representative of entrepreneurship) in ethnic entrepreneurship (Dana et al., 2020), there is a possibility that this link may not lead to successful innovation implementation in Minangkabau entrepreneurship as there are some issues in terms of social capital that is an important issue in ethnic entrepreneurship.

\subsection{Minangkabau socio-cultural values}

Cultural values in today's society have become increasingly complex issues. Societal evolution Terpstra-Tong et al. (2014), for example, found that the main ethnic groups in Malaysia, namely Malays, Chinese and Indians apparently shared the same cultural values which were previously incompatible. However, cultural values in a society with a high level of collectivism have certain characteristics. Kuran $(2004,2012)$ focused on the causes of entrepreneurial fallout in the Middle East which are associated with social and cultural changes in the region, and it was identified that the conservative Middle Eastern culture experienced a decline due to their inability to adapt to changes that at the time were being developed by the West.

Minangkabau socio-cultural values reflect the identity of the Minangkabau people themselves. Interestingly, the strong link between adat and Islamic values characterises Minangkabau cultural values Fithri, 2013) and this is also reflected in the wisdom in 'adat basandi sara'; sara 'basandi kitabullah' where Islam guides adat or tradition (Naim, 2014). Thus, it is interesting to see whether the values of Minangkabau culture are able to adapt to the social changes that occur.

\subsection{Islam, ethnicity, Minangkabau and innovation}

Islamic values are important to be explored when we discuss about Minangkabau, including in the business aspects of Minangkabau people. This is mainly due to the fact that Minangkabau people historically identified themselves as Muslims (Abdullah, 1966; Nasrun, 1971; Fithri, 2013; Sari, 2014). Sakai and Fauzia (2014) identified that Minangkabau people are one of the most religious Muslim communities in Indonesia. Some previous studies (e.g., Dana et al., 2020; Anggadwita et al., 2017) generally 
emphasised the strong support from Islamic values to entrepreneurship and innovation as Muslims are encouraged to have innovative behaviour and be generous, benevolent, and cooperative. However, there are not many studies that confirm the relationship between Minangkabau values and innovation. Of the few, a Games (2015) study found that there was no strong relationship between the values of Minangkabau culture and innovation. The most important reason for that was a lack of trust among Minangkabau entrepreneurs as although they are collectivistic in their social life, they tend to be more individualistic in business (Games et al., 2013). This is a reminder that the strength of these values in a society does not necessarily mean that it affects business innovation.

Regarding ethnicity, this concept refers to cultural identity in a group within a nation (Hirschman, 2001; Lin and Kelsey, 2000). Aldrich and Waldinger (1990) identified a reciprocal relationship between ethnicity and entrepreneurism. In particular, ethnicity can be a network and resource base for entrepreneurs; meanwhile, entrepreneurial activities can strengthen group consciousness. Thus, the concept of tribe in this study is expected to be able to show the level of ethnicity and its relationship with the use and business network to achieve success in implementing innovation.

Ethnic entrepreneurship concept sees social capital as a source of cultural values and tradition that enhance entrepreneurship (Dana et al., 2020). Here social capital is formed by social interaction and trust among those with similar ethnicity. They are less educated with no assets, so they have more reliance on their inner group. That is why future entrepreneurs in this regard need to clearly show some expected characteristics that resemble Islamic teachings such as siddiq (truthful) and tabligh (e.g., be effective communicators) as a way to preserve networks (Anggadwita et al., 2017).

A study by Rehman and Askari (2010) examined how far Islamic teachings are understood and influences the behaviour of Muslim societies in a state and social life. The basic teachings of Islam which are used as indicators are taken from the Qur'an and hadith, grouped into five aspects. First, Islamic teachings concerning one's relationship with God and human relations. Second, the economic system and the principle of justice in politics and social life. Third, the legal system and government. Fourth, human rights and political rights. Fifth, Islamic teachings are related to international relations and non-Muslim communities. As a result, Islamic countries are ranked lower compared to Western secular countries such as New Zealand and Ireland.

A qualitative research by Suprihadi and Rokhmawati (1994) on religiosity in Minangkabau businessmen found that religiosity motivated the implementation of business ethics in their business organisations. Interviewees in the research stated that running a business is in accordance with Islamic guidance and not doing business only for profit alone to be something they hold fast to. Sharing with others, especially the poor, is also important to them. This signifies that religiosity can be an essential element in running a business for Minangkabau people.

\subsection{Relationship between Minangkabau values, ethnicity and innovation outcomes}

The relationship between Minangkabau values and innovation can be found in their traditions. Minangkabau people are regarded as entrepreneurs, mainly because of their migration tradition, although Effendi (1999) argues that Minangkabau entrepreneurship is driven by economic and pragmatic reasons. As mentioned earlier, migration is an 
important tradition in Minangkabau culture (Kato, 2007) and voluntary migration (merantau) has been encouraged. Adat (culture) can partly explain this phenomenon (Abdullah, 1966). However, some researchers argue against the Minangkabau people as a source of potential businessmen. While Minangkabau people have been known to be involved in business activities throughout Indonesia, they are generally small traders, rather than growth-oriented entrepreneurs, that focus on traditional markets such as embroidery and handicrafts (Effendi, 1999). However, Games (2015) found that Minangkabau SME owners can accelerate their business innovation if the right approach is available to them. There is a strong connection between Minangkabau business owners and Minangkabau culture.

The present study uses the conceptualisation of innovation outcomes used by Simpson et al. (2006) to represent Minangkabau SME innovation. They identify that firm innovativeness may have an effect on innovation outcomes, namely positive outcomes and negative outcomes which in turn lead to firm financial performance. Positive outcomes include type of innovation (quality, number, and speed), market advantage, operational excellence, and market advantage. Further, negative outcomes include increased costs, employee attitude (turnover, job stress), market risks, and innovation beyond core competencies. Accordingly, the most important task of SMEs will be how to benefit from innovation, while at the same time reduce its negative effects. Additionally, SME owners may have no idea about how to successfully implement business innovation. Rosenbusch et al. (2011) suggested that the main reason the factors influencing successful SME innovation have not been fully identified is because there are so many factors that influence success or failure. Essentially, SMEs need to be able to identify their business strategies in order to benefit from innovation.

The strong link between religion and culture in the Minangkabau ethnic group makes Minangkabau cultural values an identity that is in harmony with religiosity, especially Islam, as shown by research by Suprihadi and Rokhmawati (1994). However, a number of studies show that religiosity is not enough to improve innovation outcomes. A study by Games (2015) shows that the relationship between Minangkabau culture and innovation outcomes is not significant, and that it could be due to a number of studies showing the opposite possibilities and outcomes. Bénabou et al. (2015) also found that religiosity at the individual level has no connection with innovation and even converged on counter-innovative behaviour; while at the country/ community level the same thing was found (van Herk and Poortinga, 2012).

Based on the results of previous research, the following hypothesis was formulated:

H1 Minangkabau values are negatively related to innovation outcomes.

\subsection{Minangkabau culture, religiosity and innovation outcomes}

Previous research has identified the relationship between religiosity and personal values. Schwartz and Huismans (1995) found that people who value certainty and self-control tend to be more religious, while people who value openness to change and have free self-expression tend to be less religious. Some studies have suggested that religious people may find it difficult to innovate. Van Herk and Poortinga (2012) found that religious people have a tendency to accept traditional values rather than changes which lead to low economic growth. 
Saroglou et al. (2004) replicated Rokeach's (1969) study and found that religious people tend to support values that encourage the conservation of social and individual settings (tradition, conformity, and to a lesser extent, security). Religious people also do not like values that encourage openness to change and autonomy (stimulation, self-direction) and support values that allow for limited self-transcendence (virtue, but not universalism). They also dislike hedonism and, to a lesser extent, values that promote self-improvement (achievement and strength). Thus, religious people may be more reluctant to make changes or innovate. However, previous research on religiosity and values has been carried out in developed countries which are predominantly Christian. Little is known about the impact of religiosity on the values of Muslims living in developing countries. It is also a marker that the research context can be a distinguishing factor of research results.

Weber (2002) suggested that the Protestant Work Ethics had a major influence on the ethos of people in the Western world. The Protestant work ethic emphasises the pursuit of economic prosperity through hard work, honesty and innovation. In addition, many US entrepreneurs consider themselves religious, perhaps because their religion encourages people to have personal ambitions and innovations (Dougherty et al., 2013). These entrepreneurs also see church congregations as the main source of social capital in the USA.

Adas (2006) argues that Muslims conform to entrepreneurial values, although Weber (2002) states that it may be difficult for Muslims to imitate Protestant work ethics. Arslan (2001) also argues that Protestant work ethics can be implemented in other religious communities, but notes that there are obstacles in the Muslim community. For example, Sufism and autocracy can reduce the effectiveness of Protestant work ethics. It seems that personal and cultural values may influence how Muslims play their role in society, including as business actors.

Jafari and Süerdem (2012) found that, for most of its followers, Islam was seen as a culture and not a dogmatic institution. Marsh (2012) notes that traditional Muslim values cover the five pillars of the profession of faith ('There is no God but Allah, and Muhammad is his messenger', daily prayers, alms giving, fasting during the month of Ramadan, and pilgrimage to Mecca). He also included the views of men as protectors of women as traditional Muslim values. Thus, the values of Islam include many things from the aspects of ritual, traditional, and practices in a society.

Although religiosity has an important role as a form of identity for Minangkabau people, there is no strong indication that religiosity is able to further strengthen their tendency to have Minangkabau cultural values that will result in high business innovation achievements (Games et al., 2013). There is no research that specifically addresses this matter. However, the role of religiosity as a moderating variable has been identified in many studies and, in the context of innovation in the west, it was found to have no effect (Bénabou et al., 2015). Likewise, in the Minangkabau context, religiosity is not yet identified to be a strong enough factor to moderate behaviour change (Sari, 2014). Butt et al. (2014) suspect that one of the reasons why religiosity has no effect in a number of known religious contexts is that it could be due to the measurement factor of the variable itself. Inappropriate selection in the context of a strong Islamic community can lead to weak moderation. Thus, Islamic values may not be able to be transformed in the form of innovation-based business practices and are able to derive benefits from innovation. 
Based on the suggestions of previous research findings as stated above, the following hypotheses are formulated:

H2 Ethnicity is negatively related to innovation outcomes.

H3 Religiosity does not moderate the relationship between Minangkabau culture and the innovation outcomes.

H4 Religiosity does not moderate the relationship between Minangkabau culture and innovation outcomes.

The research model that can provide an overview of the possible role of values and religiosity on innovation can be seen in Figure 1.

Figure 1 Research model (see online version for colours)

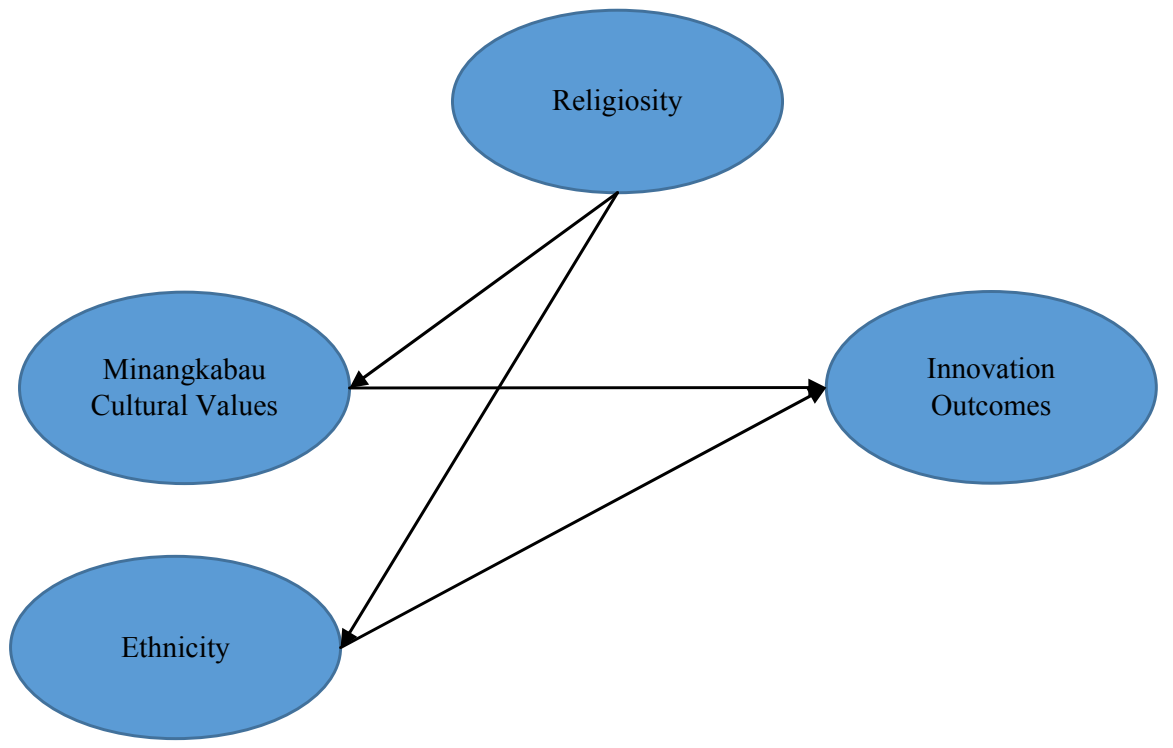

\section{Research approach and methodology}

This study uses a quantitative approach. While this approach may not result in a deeper understanding regarding the phenomenon of entrepreneurship (Dana and Dana, 2005), it can provide some explanations regarding Minangkabau entrepreneurship. It is important to have entrepreneurship research that is connected to the context that captures the essence of entrepreneurship (Frank and Landstrớm, 2015). The method used is PLS (partial least square) with WarpPLS 4.0. A total of 150 Minangkabau SME owners were surveyed using purposive sampling by considering these criterions: having an identity as a Minangkabau and Muslim; having and engaging in a business for at least 2 years; minimum age of 23 years; and having a minimum turnover of USD 35,000 per year. The present study used survey method and was done by submitting a questionnaire and giving small businesses time to answer before submitting it at the specified time (self-administration survey). 


\subsection{Measurement}

This study has four variables, namely Minangkabau values and ethnicity (as independent variables), religiosity (a moderator variable), and innovation outcomes (a dependent variable). This study uses a Likert Scale ( 1 to 5 of $1=$ strongly disagree to $5=$ very strongly agree). For Minangkabau societal values, this study uses Games' (2015) measurement which has formulated 5 items which are a blend of Minangkabau societal values that guide Minangkabau people. These are "Minangkabau values significantly influence my life; Minangkabau values encourage innovation"; "You prefer to run a business with other Minangkabau people"; "Minangkabau SME owners have better skills and capability in running business than other ethnic groups in Indonesia"; and "Islam significantly influences the way you conduct your business".

Ethnicity was measured using items from 'the multi-group ethnic identity measure' (MEIM-R) (Phinney, 1992). Religiosity was measured using items adopted from by Butt et al. (2014) who have formulated measurements of religiosity that are more relevant to Muslims compared to, for example, measurements that have often been used, such as from Allport and Ross (1967). Finally, innovation outcome was measured using items used by Simpson et al. (2006) which include positive innovation outcomes Positive outcomes include type of innovation (quality, number, speed), market advantage, and operational excellence.

\subsection{Data analysis}

The data in this study were analysed using the PLS method using SmartPLS 4.0. Validity and reliability tests are carried out and furthermore structural model estimates will be analyzed so that the objectives of this research can be achieved. The SmartPLS estimates the probability ( $\mathrm{p}$ ) of the value for the path coefficient in the model through the bootstrap procedure. These $\mathrm{p}$ values are very important when interpreting results because they reflect the strength of the relationship. Furthermore, SmartPLS is also used to see the possibility of religiosity being able to moderate the relationship between cultural values and achievement of innovation. Testing the strength of moderation variables (religiosity) can be done by estimating the interaction path coefficients and determining their statistical significance (Kock, 2013).

\section{Results}

\subsection{Validity and reliability}

Of 150 respondents who are small business owners, 87 are men and 53 are women. 50\% of the respondents aged below 30. A majority of the respondents (55\%) have run their business for 5 years. All of them are Minangkabau and Muslim. In terms of discriminant validity, Table 1 shows that the correlation value of each indicator in the latent variable is higher than the correlation between indicators in the other variables. So, the results of the cross-loading table have shown good and valid discriminant validity. 
Table 1 Cross loading results

\begin{tabular}{lcccccc}
\hline & $\begin{array}{c}\text { Ethnicity } \\
(\text { ET) }\end{array}$ & $\begin{array}{c}\text { Minangkabau } \\
\text { societal } \\
\text { values }(M V)\end{array}$ & $\begin{array}{c}\text { Religiosity } \\
(\text { RG })\end{array}$ & $\begin{array}{c}\text { Innovation } \\
\text { outcomes } \\
(I O)\end{array}$ & $\begin{array}{c}\text { Moderating } \\
\text { effect 1 }\end{array}$ & $\begin{array}{c}\text { Moderating } \\
\text { effect 2 }\end{array}$ \\
\hline ET1 & $\mathbf{0 . 5 4 2}$ & 0.260 & 0.230 & 0.081 & -0.357 & -0.155 \\
ET3 & $\mathbf{0 . 6 9 7}$ & 0.354 & 0.221 & 0.215 & -0.173 & 0.062 \\
ET4 & $\mathbf{0 . 6 4 6}$ & 0.260 & 0.081 & 0.186 & -0.169 & -0.047 \\
ET5 & $\mathbf{0 . 7 7 0}$ & 0.362 & 0.048 & 0.230 & -0.259 & -0.095 \\
MV3 & 0.326 & $\mathbf{0 . 7 9 4}$ & 0.111 & 0.280 & -0.001 & -0.112 \\
MV4 & 0.412 & $\mathbf{0 . 7 8 8}$ & 0.255 & 0.277 & -0.109 & -0.083 \\
RG13 & -0.154 & -0.238 & $\mathbf{- 0 . 6 6 0}$ & -0.151 & -0.129 & -0.131 \\
RG14 & -0.145 & -0.132 & $\mathbf{- 0 . 5 3 7}$ & -0.047 & -0.074 & -0.091 \\
RG27 & 0.097 & 0.131 & $\mathbf{0 . 5 5 3}$ & 0.130 & 0.009 & 0.015 \\
RG34 & -0.177 & -0.168 & $\mathbf{- 0 . 5 4 8}$ & -0.103 & -0.160 & -0.163 \\
RG37 & 0.056 & 0.131 & $\mathbf{0 . 5 7 7}$ & 0.123 & 0.023 & 0.198 \\
RG7 & 0.223 & 0.110 & $\mathbf{0 . 6 5 5}$ & 0.104 & 0.046 & 0.233 \\
RG9 & 0.038 & 0.087 & $\mathbf{0 . 6 9 4}$ & 0.186 & 0.070 & 0.121 \\
IO3 & 0.286 & 0.363 & 0.152 & $\mathbf{0 . 9 2 7}$ & 0.058 & -0.010 \\
IO4 & 0.094 & 0.094 & 0.222 & $\mathbf{0 . 5 0 0}$ & 0.047 & 0.147 \\
ET * RG & -0.320 & -0.069 & 0.117 & 0.069 & $\mathbf{1 . 0 0 0}$ & 0.510 \\
MV * RG & -0.061 & -0.124 & 0.218 & 0.047 & 0.510 & $\mathbf{1 . 0 0 0}$ \\
\hline
\end{tabular}

AVE also indicates discriminant validity and the expected valid AVE scores is $>0.5$ and this has been fulfilled as can be seen from Table 2 .

Table 2 Average variance extracted (AVE)

\begin{tabular}{lcc}
\hline & AVE & Square root of $A V E$ \\
\hline ET & 0.51 & 0.71 \\
MV & 0.63 & 0.80 \\
RG & 0.60 & 0.75 \\
IO & 0.60 & 0,74 \\
ET * RG & 0.90 & 0.90 \\
MV * RG & 0.90 & 0.90 \\
\hline
\end{tabular}

In terms of reliability, as can be seen from Table 3, Cronbach's alpha for some of the variables were below 0.6 , but the composite reliability was higher than 0.7 . Therefore, this indicated that further analysis is viable. 
Table 3 Cronbach's alpha and composite reliability

\begin{tabular}{lcc}
\hline & Cronbach's alpha & Composite reliability \\
\hline ET & 0.519 & 0.757 \\
IO & 0.544 & 0.768 \\
MV & 0.502 & 0.770 \\
ET * RG & 0.901 & 0.901 \\
MV * RG & 0.900 & 0.900 \\
RG & 0.522 & 0.723 \\
\hline
\end{tabular}

\subsection{Structure model (inner model)}

Based on Table 4, it can be seen that the Minangkabau values (MV) has a positive effect on innovation outcomes (IO) with a value of t-statistic $2.972>1.64$ and P-values $0.003<0.05$ so it can be concluded that Hypothesis 1 is not supported as Minangkabau values has a positive and significant effect on Innovation outcome. In addition, ethnicity (ET) was not found to be significantly related to innovation outcomes as P-values $(0.051)>0.05$.

Table 4 Path coefficients

\begin{tabular}{lccccc}
\hline & $\begin{array}{c}\text { Original } \\
\text { sample }(O)\end{array}$ & $\begin{array}{c}\text { Sample } \\
\text { mean }(M)\end{array}$ & $\begin{array}{c}\text { Standard } \\
\text { deviation } \\
(\text { STDEV })\end{array}$ & $\begin{array}{c}\text { t-Statistic } \\
(\mid \text { OSTDEV })\end{array}$ & P-values \\
\hline $\mathrm{ET}>\mathrm{IO}$ & 0.177 & 0.186 & 0.091 & 1.956 & 0.051 \\
$\mathrm{MV}>\mathrm{IO}$ & 0.259 & 0.264 & 0.087 & 2.972 & 0.003 \\
$\mathrm{ET} * \mathrm{RG}$ & 0.150 & 0.110 & 0.125 & 1.206 & 0.228 \\
$\mathrm{MV} * \mathrm{RG}$ & 0.074 & 0.052 & 0.089 & 0.833 & 0.405 \\
$\mathrm{RG}>\mathrm{IO}$ & 0.119 & 0.126 & 0.112 & 1.065 & 0.287 \\
\hline
\end{tabular}

In terms of religiosity as a moderating variable in the third hypothesis (H3), from Table 5 it can be seen that the t-statistic is 0.833 which is less than 1.64 and P-values 0.405 , so that it can be concluded that religiosity did not moderate the relationship between Minangkabau societal values and innovation outcome, which means the third hypothesis (H3) was supported. For H4, table 5 shows that the t-statistic (1.206) is less than 1.64 and $\mathrm{P}$ values $0.245>0.05$, so that it can be concluded that religiosity did not moderate the relationship between ethnicity (ET) and innovation outcome (IO), which means the fourth hypothesis (H4) is supported.

Table 5 The role of religiosity as moderator

\begin{tabular}{lccc}
\hline & Original sample $(O)$ & t-statistic $(\mid 0 /$ STDEV $)$ & $P$ values \\
\hline $\mathrm{ET} * \mathrm{RG}$ & 0.074 & 0.833 & 0.405 \\
$\mathrm{MV} * \mathrm{RG}$ & 0.150 & 1.206 & 0.228 \\
\hline
\end{tabular}

A summary of the results of the present study can be seen in Table 6 . 
Table 6 A summary of the results

\begin{tabular}{llc}
\hline & \multicolumn{1}{c}{ Hypotheses } & Results \\
\hline H1 & $\begin{array}{l}\text { Minangkabau societal values are negatively related to } \\
\text { innovation outcomes }\end{array}$ & Not supported \\
H2 & $\begin{array}{l}\text { Ethnicity is negatively related to innovation outcomes } \\
\text { H3 }\end{array}$ & $\begin{array}{l}\text { Religiosity does not moderate the link between } \\
\text { Minangkabau values and innovation outcomes }\end{array}$ \\
H4 & $\begin{array}{l}\text { Religiosity does not moderate the link between } \\
\text { ethnicity and innovation outcomes }\end{array}$ & Supported \\
\hline
\end{tabular}

\section{Discussion}

Elfindri et al. (2010) indicates that Minangkabau people have a concern and sense of ownership towards the Minangkabau ethnic group. Furthermore, Games and Rendi (2019) found that there was a higher level of innovation outcomes in Minangkabau SMEs that come from their innovative behaviour. In the present study, it was found that Minangkabau values had a positive and significant effect on SME innovation outcomes. This finding contradicts the results of Games (2015) research which showed that Minangkabau values were not related to achievement of innovation, while in many cases, as suggested by van Herk and Poortinga (2012) that religious people have a tendency not to embrace changes. Possible explanations for this result are profiles of respondents who are mostly under 40 years old. They are, for example, the millennial Minangkabau generation who are more independent and creative in their business (Games, 2015). They could have pragmatic principles but respect the universal values contained in religion and customs. This finding is in line with previous studies (e.g., Dana et al., 2020; Anggadwita et al., 2017) that emphasise the notion that there are strong links between cultural values, social capital, Islamic values and entrepreneurship. This means that Minangkabau values, as a combination of both Islamic values and Minangkabau cultural values, support Minangkabau entrepreneurship.

This research also found that ethnicity did not affect innovation outcomes. This means that attachment and pride towards Minangkabau culture per se does not lead respondents to a better level of innovation outcomes. Rather, Minangkabau values that contain attachment to Islam and essence of Minangkabau culture were more influential in doing business innovation. Perhaps one of the reasons why this happens is from the perspectives of Aldrich and Waldinger (1990) and Dana et al.'s (2020) studies that identified a reciprocal relationship between ethnicity and entrepreneurship. Ethnicity can be a network and resource base for entrepreneurs; meanwhile, entrepreneurial activities can strengthen group consciousness. The possibility of taking ethnicity into account does not strengthen the marketing base for MSME entrepreneurs as they have not established tribal based business partnerships.

The role of religiosity as a moderator variable was not found in the relationship between Minangkabau societal values, ethnicity, and innovation outcomes. Regarding the link between religiosity and the Minangkabau societal values, the research finding is in line with research from Sari (2014) which shows that religiosity did not moderate the behaviour of Minangkabau consumers. Likewise, in the Western context, the role of religiosity as a moderating variable has been identified in many studies and in the context 
of innovation has been found to have no effect (e.g., Bénabou et al., 2015). It is possible that the reason for that is as stated by Jafari and Süerdem (2012) who identify that, for most followers, Islam is seen as a culture and not a dogmatic institution. In this case, religiosity may be embedded in Minangkabau values construct in the present study, which is in line with a study by Dana (2009) that argues that entrepreneurs may be influenced by cultural values that are essentially taken from religious values, specifically Islamic values in the case of Minangkabau entrepreneurship .

In a broader sense, the finding of the present study encourages business partnership that benefits from Minangkabau networks. This can be a valuable asset to initiate partnership and assistance from external actors which is in line with a study by Galbraith et al. (2007) that argued that ethnic entrepreneurs are expected to share and interact with other people from different ethnic groups as this is potentially expand their business and support cultural assimilation. As also suggested by Goyal et al. (2018), it is important for entrepreneurs to have personal and long-term relationship with main stakeholders. Accordingly, business owners may need external funding as their inner group cannot provide that, and this, as suggested by Li and Tang (2017), can contribute positively to business innovation. This trajectory may be followed by Minangkabau entrepreneurs as a way to transform their business into innovative and high-growth businesses.

\section{Conclusions}

This research has provided a new perspective related to the study of entrepreneurship and socio-cultural factors including social values, ethnicity, and religiosity. It was found that in the Minangkabau SME, which was entirely Muslim, the Minangkabau societal values which were a mixture of culture and Islam have had a positive and significant effect on innovation outcomes. This shows that it is true that Islam and ethnicity have combined together and are difficult to separate in the Minangkabau context. It was also found that ethnicity had no effect on innovation outcomes and religiosity did not moderate the relationships between ethnicity, Minangkabau societal values and SME innovation outcomes. This may indicate the importance of the essence of culture and Islam as a guide and life identity for Minangkabau people rather than tribal sentiments and religious symbolism per se.

\subsection{Implications}

The present study found that Minangkabau societal values that are unique for Minangkabau have had significant and positive impact on innovation outcomes. In this case, Minangkabau societal values represent respondents' belief in Islamic and cultural values which guide their lives as business actors as well as their self-confidence as entrepreneurs. Here, religion was not seen as symbolism per se which may require Minangkabau entrepreneurs to show genuine ethical behaviours such as honesty and fairness. Implicitly, maximising Minangkabau networks that prioritises the values of cooperation, honesty and trustworthiness will enhance Minangkabau SME innovation outcomes. These are valuable assets to help implement open innovation in which they can benefit from external assistance as continuation of their Minangkabau networks. 


\subsection{Limitations of research and future research}

As with most research, the present study also has limitations. The diversity of research respondents are limited and all of them resided in homogeneous West Sumatra (almost all of them Minangkabau and Muslim). Thus, further studies are needed with respondents who run their business outside West Sumatra which can provide additional perspectives as they may be a minority group in those areas. In addition, the variable of Minangkabau societal values in this study is formulated based on qualitative research in 2013. This has been specifically designed exclusively for the Minangkabau people in which entrepreneurship, collectivism, and religion (Islam), and customs are interlinked. It is possible to make changes or additions to Minangkabau societal values which may be more relevant for the modern Minangkabau people including Minangkabau entrepreneurs. In addition, as suggested by Dana and Dana (2005), qualitative approach that captures the deeper understanding of entrepreneurship phenomenon, for example, Minangkabau social capital and business networks, can be worthwhile. While comparison between ethnic groups with similar or different characteristics can be conducted, future research may also explore the link between ethnicity, religiosity and some innovation related construct such as innovation implementation, creativity, and risk-taking in different contexts such as in more heterogeneous settings.

\section{References}

Abdullah, T. (1966) 'Adat and Islam: an examination of conflict in Minangkabau', Indonesia, Vol. 2, pp.1-24.

Adas, E. (2006) 'The making of entrepreneurial Islam and the Islamic spirit of capitalism', Journal for Cultural Research, Vol. 10, No. 2, pp.113-137.

Aldrich, H.E. and Waldinger, R. (1990) 'Ethnicity and entrepreneurship', Annual Review of Sociology, Vol. 16, No. 1, pp.111-135.

Allport, G.W. and Ross, J.M. (1967) 'Personal religious orientation and prejudice', Journal of Personality and Social Psychology, Vol. 5, No. 4, pp.432-443.

Amabile, T.M. (1996) Creativity in Context, Westview Press, Boulder, CO.

Anggadwita, G., Ramadani, V., Alamanda, D., Ratten, V. and Hashani, M. (2017) 'Entrepreneurial intentions from Islamic perspective: a study of Muslim entrepreneurs in Indonesia', International Journal of Entrepreneurship and Small Business, Vol. 31, No. 2, pp.165-179.

Arslan, M. (2001) 'The work ethic values of Protestant British, Catholic Irish and Muslim Turkish manager', Journal of Business Ethics, Vol. 31, No. 4, pp.321-339.

Bénabou, R., Ticchi, D. and Vindigni, A. (2015) 'Religion and innovation', American Economic Review, Vol. 105, No. 5, pp.346-351.

Butt, I., Ul-Haq, S. and Al Said, F. (2014) 'Scale of religiosity for Muslim: an exploratory study', GIMAC 5 2014: Proceeding GIMAC 5, Kuala Lumpur, Malaysia, pp.421-433.

Damanpour, F. (1996) 'Organizational complexity and innovation: developing and testing multiple contingency models', Management Science, Vol. 42, No. 5, pp.693-716.

Dana, L.P. (2009) 'Religion as an explanatory variable for entrepreneurship', The International Journal of Entrepreneurship and Innovation, Vol. 10, No. 2, pp.87-99.

Dana, L.P. and Dana, T.E. (2005) 'Expanding the scope of methodologies used in entrepreneurship research', International Journal of Entrepreneurship and Small Business, Vol. 2, No. 1, pp.79-88. 
Dana, L.P., Gurau, C., Light, I. and Muhammad, N. (2020) 'Family, community, and ethnic capital as entrepreneurial resources toward an integrated model', Journal of Small Business Management [online] https://doi.org/10.1111/jsbm.12507.

Dougherty, K.D., Griebel, J., Neubert, M.J. and Park, J.Z. (2013) 'A religious profile of American entrepreneurs', Journal for the Scientific Study of Religion, Vol. 52, No. 2, pp.401-409.

Effendi, N. (1999) Minangkabau Rural Markets: Their System, Roles and Functions in the Market Community of West Sumatra, Doctoral dissertation, University of Bielefeld, Germany.

Elfindri, Ayunda, D. and Saputra, W. (2010) Minang Entrepreneurship: Filosofi dan Rahasia Sukses Etnis Minang Membangun Karakter Kewirausahaan, Baduose Media, Jakarta.

Frank, H. and Landstrớm, H. (2015) 'What makes entrepreneurship research interesting? Reflections on strategies to overcome the rigour-relevance gap', Entrepreneurship \& Regional Development, Vol. 28, Nos. 1-2, pp.51-75.

Galbraith, C.S., Rodrigue, C.L. and Stiles, C.H. (2007) 'Social capital as a good club: the case of ethnic communities and entrepreneurship', Journal of Enterprising Communities and Places in the Global Economy, Vol. 1, No. 1, pp.38-53.

Games, D. (2015) An Examination of Small and Medium Enterprise Innovation in an Emerging Market, Doctoral dissertation, The University of Western Australia, Australia.

Games, D., Soutar, G. and Sneddon, J. (2013) 'Entrepreneurship, values, and Muslim values: some insights from Minangkabau entrepreneurs', International Journal of Social Entrepreneurship and Innovation, Vol. 2, No. 4, pp.361-373.

Games, D. and Rendi, R.P. (2019) 'The effects of knowledge management and risk taking on SME financial performance in creative industries in an emerging market: the mediating effect of innovation outcomes', Journal of Global Entrepreneurship Research, Vol. 1, No. 4, pp.1-14.

Goyal, S., Sergi, B.S. and Esposito, M. (2018) 'Business development service for micro, small and medium enterprises: literature review of past trends and future directions', World Review of Entrepreneurship, Management and Sustainable Development, Vol. 14, No. 3, pp.312-332.

Hirschman, E.C. (2001) 'Ethnicity, racism, and the colonization of consumption', Conference Proceedings 2001 AMA Educators, American Marketing Association, Chicago, USA, Vol. 12, pp.236-244.

Fithri, W. (2013) Mau Kemana Minangkabau?, GRE, Yogyakarta.

Kato, T. (2007) Matriliny and Migration: Evolving Minangkabau Traditions in Indonesia, Equinox Publishing, Singapore.

Kock, N. (2013) WarpPLS 4.0 User Manual, ScriptWarp Systems, Laredo, TX.

Kuran, T. (2004) 'Why the Middle East is economically underdeveloped: historical mechanisms of institutional stagnation', Journal of Economic Perspectives, Vol. 18, No. 3, pp.71-90.

Kuran, T. (2012) The Long Divergence: How Islamic Law held Back the Middle East, Princeton University Press, Princeton, NJ.

Li, H. and Tang, J. (2017) 'Technological human capital, firm innovativeness, and entrepreneurial success: the moderating role of seeking and receiving external funding', World Review of Entrepreneurship, Management and Sustainable Development, Vol. 13, No. 1, pp.106-119.

Lin, S.S. and Kelsey, J.L. (2000) 'Use of race and ethnicity in epidemiologic research: concepts, methodological issues, and suggestions for research', Epidemiologic Reviews, Vol. 22, No. 2, pp.187-202.

Mangundjaya, W.L.H. (2011) 'The correlation and impact of uncertainty avoidance to innovative behaviour: a study among Minangkabau entrepreneurs', Proceeding of the 10th International Entrepreneurship Forum, Tamkeen, Bahrain, pp.9-11.

Marsh, R.M. (2012) 'Muslim values in islamic and non-islamic societies', Comparative Sociology, Vol. 11, No. 1, pp.29-63.

Naim, M. (2014) 'Kembali ke surau, kembali bernagari', Haluan, 24 November.

Nasrun, M. (1971) Dasar Falsafah Adat Minangkabau, Bulan Bintang, Jakarta. 
Phinney, J.S. (1992) 'The multigroup ethnic identity measure: a new scale for use with diverse groups', Journal of Adolescent Research, Vol. 7, No. 2, pp.156-176.

Ramadani, V., Rexhepi, G., Gerguri-Rashiti, S., Ibraimi, S. and Dana, L.P (2014) 'Ethnic entrepreneurship in Macedonia: the case of Albanian entrepreneurs', International Journal of Entrepreneurship and Small Business, Vol. 23, No. 3, pp.313-335.

Ramadani, V., Dana, L.P., Ratten, V. and Tahiri, S. (2015) 'The context of Islamic entrepreneurship and business: concept, principles and perspectives', International Journal of Business and Globalisation, Vol. 15, No. 3, pp.244-261.

Ratam, D. (2005) Leadership and Innovation in Small to Medium Enterprises in Indonesia: A Quantitative Survey and Qualitative Multiple Case-Study Approach, PhD thesis, The University of Western Australia, Australia.

Rehman, S.S. and Askari, H. (2010) 'How Islamic are Islamic countries?', Global Economy Journal, Vol. 10, No. 2, pp.1-37.

Rokeach, M. (1969) 'Value systems in religion', Review of Religious Research, Vol. 11, No. 1, pp.2-23.

Rosenbusch, N., Brinckmann, J. and Bausch, A. (2011) 'Is innovation always beneficial? A meta-analysis of the relationship between innovation and performance in SMEs', Journal of Business Venturing, Vol. 26, No. 4, pp.441-457.

Sakai, M. and Fauzia, A. (2014) 'Islamic orientations in contemporary Indonesia: Islamism on the rise?', Asian Ethnicity, Vol. 45, No. 1, pp.41-61.

Sari, D. (2014) 'Reinventing religiosity in Minangkabau society', Simposium Muafakat Minang, UTM, Negeri Sembilan, Malaysia.

Saroglou, V., Delpierre, V. and Dernelle, R. (2004) 'Values and religiosity: a meta-analysis of studies using Schwartz's model', Personality and Individual Differences, Vol. 37, No. 4, pp.721-734.

Sawang, S. and Unsworth, K.L. (2011) 'A model of organizational innovation implementation effectiveness in small to medium firms', International Journal of Innovation Management, Vol. 15, No. 5, pp.989-1011.

Schwartz, S.H. and Huismans, S. (1995) 'Value priorities and religiosity in four western religions', Social Psychology Quarterly, Vol. 58, No. 2, pp.88-107.

Simpson, P.M., Siguaw, J.A. and Enz, C.A. (2006) 'Innovation orientation outcomes: the good and the bad', Journal of Business Research, Vol. 59, No. 10, pp.1133-1141.

Soutar, G. and McNeil, M. (1993) 'Corporate innovations: some Australian experiences', Prometheus, Vol. 11, No. 2, p.220.

Suriyankietkaew, S. (2019) 'Sustainable leadership and entrepreneurship for corporate sustainability in small enterprises: an empirical analysis', World Review of Entrepreneurship, Management and Sustainable Development, Vol. 15, Nos. 1-2, pp.256-275.

Suprihadi and Rokhmawati (1994) Perubahan struktur sosial budaya dalam pembangunan daerah: etos Kerja dan wirausaha orang Minangkabau, Pusat Penelitian dan Pengembangan Kemasyarakatan dan Kebudayaan LIPI, Jakarta.

Terpstra-Tong, J.L.Y., Terpstra, R.H. and Tee, D.D. (2014) 'Convergence and divergence of individual-level values: a study of Malaysian managers', Asian Journal of Social Psychology, Vol. 17, No. 3, pp.236-243.

van Herk, H. and Poortinga, Y.H. (2012) 'Current and historical antecedents of individual value differences across 195 regions in Europe', Journal of Cross-Cultural Psychology, Vol. 43, No. 8, pp.1229-1248.

Weber, M. (2002) The Protestant Ethic and the 'Spirit' of Capitalism and Other Writings, Edited, translated, and with an introduction and notes by P.Baehr and G.C. Wells, Penguin Books, London. 